\section{Effect of Mechanical Cycling on Screw Torque in External Hexagon Implants with and without Platform Switching}

Bruno Andrade Cantharino de Carvalho', Eduardo Vedovatto', Paulo Sérgio

Perri de Carvalho ${ }^{1}$, José Vitor Quinelli Mazaro ${ }^{1}$, Rosse Mary Falcón-Antenucci ${ }^{2}$
'Department of Oral Implantology, SLMANDIC - Faculdade São Leopoldo Mandic, Campinas, SP, Brazil ${ }^{2}$ Department of Dental Materials and Prosthodontics, Araçatuba Dental School, UNESP - Universidade Estadual Paulista, Araçatuba, SP, Brazil

Correspondence: Prof. José Vitor Quinelli Mazaro, Rua José Bonifácio, 1193 - Vila Mendonça, 16015-050 Araçatuba, SP, Brasil. Tel:+ 5518 3636-3246. e-mail: zevitormazaro@foa.unesp.br
This in vitro study evaluated the effect of mechanical cycling on the torque of retaining screw in external hexagon implants with platform switching (PS), regular platform (RP) and wide platform (WP). A total of 30 specimens were equally divided into 3 groups: PS, PR and WP. Each specimen was prepared with implants: $3.75 \times 10 \mathrm{~mm}$ for RP group and $5.0 \times 10 \mathrm{~mm}$ for PS and WP groups and its respective abutment with $32 \mathrm{Ncm}$ torque. All groups were subjected to $10^{6}$ cycles with $100 \mathrm{~N}$ (corresponding to about 40 months of chewing). The results were obtained with the reverse torque of each specimen and data were evaluated using ANOVA and Tukey test $(p<0.05)$. The PS group showed statistically significant difference in screw removal torque $(30.06 \pm 5.42)$ compared with $\operatorname{RP}(23.75 \pm 2.76)$ and WP $(21.32 \pm 3.53)(p<0.05)$ groups; the RP and WP groups showed no statistically significant difference between them. It was concluded that the PS group showed higher reverse torque value, suggesting lower susceptibility of the abutment screw loosening.
Key Words: dental implants, platform switching, reverse torque, mechanical cycling.

\section{Introduction}

The advancement of knowledge of biocompatibility and surface design of implants, biomechanics, surgical technique and bone physiology changed the profile of rehabilitation with dental implants. Thus, the single rehabilitation and functional aesthetic success of such prostheses have become a challenge for implant dentistry.

The implant-supported single prostheses with external hexagon connections undergo a variety of stresses due to the complexity of masticatory kinematics. Given this situation, in single rehabilitations, the possibility of loosening the prosthesis retaining screw is higher when compared with splinted prostheses (1). The loosening may be caused by loss or reduction of retaining screw torque, which is produced by several factors, including improper torque, lack of adaptation, large rotational freedom, failure in the screws when re-tightened, which favors wear and decreases friction between the components, making difficult the access in posterior mouth regions for screw tightening and different torques produced by mechanical devices (2-4).

Loosening generates instability at implant-abutment connection system, favoring the periimplant inflammation associated with marginal bone loss at the implant (5-7). Regarding bone loss, Lazzara and Porter (8) introduced the platform switching concept, which consisted of installing an abutment with smaller diameter than the implant platform. Thus, clinical, morphometric and biomechanical studies have proven the effectiveness of this technique in bone preservation compared with conventional technique.

Finite element studies reported that platform switching presents the biomechanical advantage of transferring the stress concentration areas at abutment and retaining screw levels (9-12), however, these studies are not specific about stress concentrated on abutment screw. Few studies have analyzed stresses in prosthetic components (13) and such stresses can cause screw loosening or fracture, which is often observed in conventional implant supported prostheses $(1,14)$.

The aim of this study was to evaluate the effect of mechanical cycling on retaining screw torque in platform switching (PS), regular platform (RP) and wide platform (WP) connections in external hexagon implants. The research hypothesis was that the mechanical cycling would increase the reverse torque value on the retaining screw of platform switching.

\section{Material and Methods}

A total of 30 specimens consisting of one implant (4.1 $\mathrm{mm}$ or $5 \mathrm{~mm}$ in diameter) and one abutment (SIN, National Implant System, SP, Brazil) were fabricated. The specimens were divided into 3 groups with 10 elements each: the platform switching (PS), regular platform (RP) and wide platform (WP), on which $3 \mathrm{~mm}$-high straight abutments were installed. The implant components were set using square screws as specified in Table 1. The used alloy was ASTM F 136 gr 5 (Dynamet, Washington, PA, USA).

Specimens were prepared using a device that allowed 
their mounting on an acrylic resin base with 0.5 inch diameter and $15 \mathrm{~mm}$ high, on which each implant was positioned at a $30^{\circ}$ angle to the ground.

Screws were torqued at $32 \mathrm{~N}$ as recommended by the manufacturer. After $10 \mathrm{~min}$, the specimens were torqued again (15).

The fatigue test was performed with equipment that simulates mechanical cycling (Elquip, São Paulo, SP, Brazil) (Figs. 1A and 1B). A total of 1,000,000 cycles was carried, at $2 \mathrm{~Hz}$ frequency, $100 \mathrm{~N}$ force and a temperature of $37 \pm 1$ ${ }^{\circ} \mathrm{C}$, according to ISO 14801 , which corresponds to about 40 months of chewing (16). After mechanical cycling, the connection screw reverse torque was performed with a digital torquimeter (TQ-8800; IMPAC São Paulo, SP, Brazil), values were tabulated and compared among groups using ANOVA and Tukey test with a 5\% significance level. Screws were evaluated using scanning electron microscopy (SEM) in order to verify the presence of deformation (Figs. 2A-C).

\section{Results}

Specifically evaluating each group and its changes when submitted to $32 \mathrm{Ncm}$ initial torque, the following values were obtained (Table 2): for test group PS the mean percentage was $93.94 \%$, while for the other groups, the

Table 1. Specifications of implants, components and abutment screw

\begin{tabular}{lccc}
\hline Platform & $\begin{array}{c}\text { Specifications } \\
\text { lmplant }\end{array}$ & $\begin{array}{c}\text { Specifications } \\
\text { abutment }\end{array}$ & $\begin{array}{c}\text { Abutment } \\
\text { screw }\end{array}$ \\
\hline $\begin{array}{l}\text { Platform switching } \\
\text { (PS), n=10 }\end{array}$ & SIN (SA 510) & Al 4153 & $\begin{array}{c}\text { Square } \\
\text { PTQ 2008 }\end{array}$ \\
$\begin{array}{l}\text { Regular platform } \\
\text { (RP), } n=10\end{array}$ & SIN (SA 310) & Al 4153 & $\begin{array}{c}\text { Square } \\
\text { PTQ 2008 }\end{array}$ \\
$\begin{array}{l}\text { Wide platform } \\
\text { (WP), } n=10\end{array}$ & SIN (SA 510) & Al 5053 & Square \\
\hline
\end{tabular}

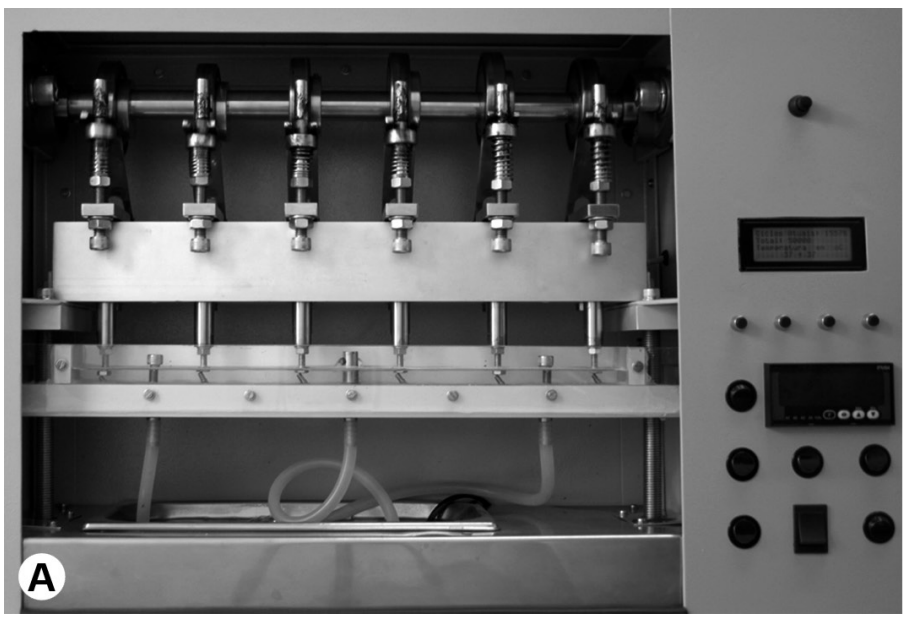

values were $74.22 \%$ and $66.63 \%$ for $\mathrm{RP}$ and WP respectively. The PS group presented a mean reverse torque closest to the initial torque, which is $93.94 \%$, suggesting a smaller possibility to loosening compared with the other groups.

SEM images of the screws after mechanical cycling are displayed in Figures 2A-C. After qualitative comparative analysis, ultrastructural alterations, such as cracks or deformations were not observed. Statistically significant difference was observed among the groups $(p=0.0001)$.

\section{Discussion}

This study investigated the effect of mechanical cycling on retaining screw torque in platform switching, regular platform and wide platform connections. A total of $1,000,000$ cycles were carried out, according to Khraisat et al. (16), because the objective was to evaluate the reverse torque and not the failure. For this study, which was performed with $100 \mathrm{~N}$ load, acrylic resin was used in the base, because it has enough flexural strength.

The results confirm the hypothesis about the increased reverse torque on the screw of platform switching group. In the studied group (PS), the results showed reverse torque values $(36.2 \mathrm{Ncm})$, higher than the initial torque $(32 \mathrm{Ncm})$ and their average $(30.06 \mathrm{Ncm})$ presented statistically significant difference when compared with the others.

The fact that high reverse torque values were found in platform switching may be explained because the highest stress concentration in platform switching is located in the retaining screw, as reported by Maeda et al. (9) and Cimen and Yengin (10), by means of finite element analyses. Therefore, stresses toward the internal implant threads increase friction with the threads of abutment connection screw during mechanical cycling and consequently increase reverse torque value, decreasing the possibility of loosening.

The RP and WP groups exhibited lower reverse torque

Figure 1. A. Mechanical cycling machine; B. Sample submitted to mechanical cycling. 
values (74.22\% and $66.63 \%$ respectively) probably due to the larger contact area between abutment and implant platform when compared to the PS group. In situations

Table 2. Numerical evaluation and percentage of reverse torques obtained after mechanical cycling in each specimen and the mean percentage of each group

\begin{tabular}{|c|c|c|c|}
\hline Implants & $\begin{array}{l}\text { Reverse torque } \\
\text { after cycling } \mathrm{Ncm}\end{array}$ & $\begin{array}{l}\text { Percentage } \\
\text { difference }\end{array}$ & $\begin{array}{c}\text { Mean } \\
\text { percentage }\end{array}$ \\
\hline 1 & 32 & 100.0 & 93.9 \\
\hline 11 & 34 & 106.3 & \\
\hline 111 & 30.1 & 94.1 & \\
\hline IV & 28.4 & 88.8 & \\
\hline V & 36.2 & 113.1 & \\
\hline $\mathrm{Vl}$ & 26.8 & 83.8 & \\
\hline Vll & 27.7 & 86.6 & \\
\hline VIII & 32.4 & 101.3 & \\
\hline IX & 35.4 & 110.6 & \\
\hline$x$ & 17.6 & 55.0 & \\
\hline $\mathrm{X} 1$ & 20.1 & 62.8 & 74.2 \\
\hline XII & 28 & 87.5 & \\
\hline XIII & 28.2 & 88.1 & \\
\hline XIV & 22.8 & 71.2 & \\
\hline $\mathrm{XV}$ & 23.6 & 73.8 & \\
\hline $\mathrm{XV} 1$ & 24.2 & 75.6 & \\
\hline $\mathrm{XV} 11$ & 22 & 68.8 & \\
\hline XVIII & 20.2 & 63.1 & \\
\hline $\mathrm{XIX}$ & 24.5 & 76.6 & \\
\hline$X X$ & 23.9 & 74.7 & \\
\hline$X X 1$ & 21.9 & 68.4 & 66.6 \\
\hline XXI1 & 25.4 & 79.4 & \\
\hline XXIII & 24.7 & 77.2 & \\
\hline XIV & 26.8 & 83.8 & \\
\hline$X X V$ & 18.1 & 56.6 & \\
\hline $\mathrm{XXVI}$ & 16.5 & 51.6 & \\
\hline XXVII & 22.1 & 69.1 & \\
\hline XXVIII & 20.9 & 65.3 & \\
\hline XXIX & 17.3 & 54.1 & \\
\hline$X X X$ & 19.5 & 60.9 & \\
\hline
\end{tabular}

where there is complete and greater contact between the component and the platform, the displacement of the abutment under oblique load results in higher torque on the screw and consequently the torque loss, also observed in other studies $(13,17)$.

According to some authors $(9,10)$, because of stress concentration on the retaining screw, it could undergo a greater deformation. However, it was not confirmed by SEM images obtained for PS group when compared with RP and WP groups. The SEM images showed no significant differences between the three groups, what concurs with the results of a SEM study where no difference was observed between RP and PS groups, in relation to the screw deformation (13). Seemingly, the loss of torque values in this study was not harmful to the implant/abutment junction, but there is no minimum value of torque loss for appropriate implant-supported prostheses performance (21).

Some studies evaluated the reverse torque and loosening of abutment retaining screw, $(16,18-21)$, but none of these studies evaluated the loosening and reverse torque in platform switching connections and external hexagon implants. The results of the current study corroborate the findings in literature regarding reverse torque values found in implant/abutment connections with external hexagon after mechanical cycling test, as found by Cibirka et al. (18), for RP and WP groups.

Based on the results obtained in this study, platform switching seems to be a viable option for the screw torque maintenance. However, many factors (screw material, crown material, prosthetic connection) could influence the loss of torque. Further research is required to elucidate some aspects, such as the fatigue strength evaluation of the screws in platform switching connections associated with external hexagon implants. Within the limitations of the used methodology, the following conclusion can be drawn: the PS group showed higher reverse torque, suggesting lower susceptibility to loosen the abutment retaining screw.

\section{Resumo}

Este estudo in vitro avaliou o efeito da ciclagem mecânica no torque dos parafusos de retenção em implantes de hexágono externo com plataforma
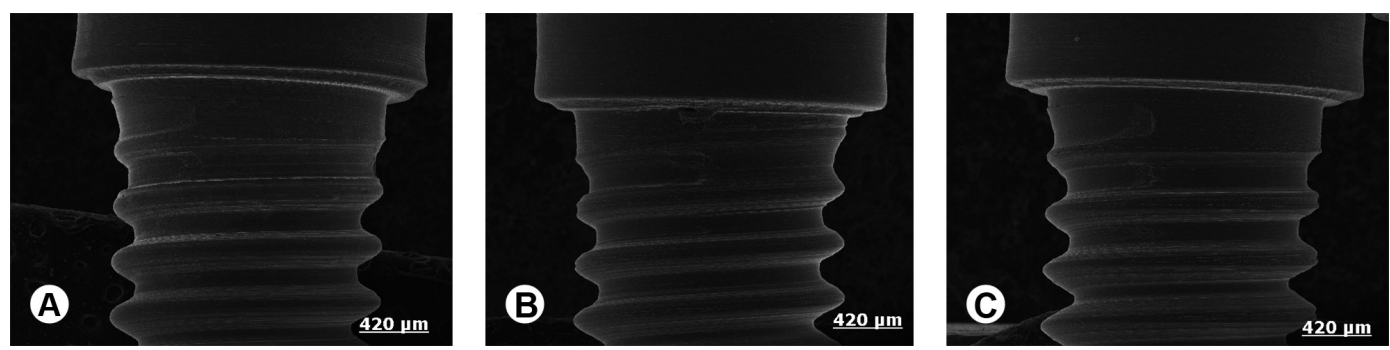

Figure 2. SEM images of screws after mechanical cycling. A: platform switching. B: regular platform. C: wide platform. 
switching (PS), plataforma regular (RP) e plataforma larga (WP). Foram utilizados 30 corpos de prova divididos em 3 grupos equitativamente: PS, RP e WP. Cada corpo de prova foi preparado com implantes: $3,75 \times 10 \mathrm{~mm}$ para o grupo RP e 5,0×10 mm para os grupos PS e WP, e seu respectivo abutment com o torque de $32 \mathrm{Ncm}$. Todos os grupos foram submetidos a $10^{6}$ ciclos com $100 \mathrm{~N}$ de força (o que corresponde a aproximadamente 40 meses de mastigação). Os resultados foram obtidos com o torque reverso de cada espécime e os dados foram avaliados com ANOVA comparado com o teste de Tukey $(p<0,05)$. 0 grupo PS apresentou diferença estatisticamente significante no torque de remoção do parafuso $(30,06 \pm 5,42)$ comparado com os grupos RP $(23,75 \pm 2,76)$ e WP $(21,32 \pm 3,53)(p<0,05)$; os grupos $\mathrm{RP}$ e WP não apresentaram diferença estatisticamente significante entre si. Concluiu-se que o grupo PS apresentou maior valor de torque reverso sugerindo menor susceptibilidade de afrouxamento do parafuso de fixação do abutment.

\section{References}

1. Jemt T, Laney WR, Harris D, Henry PJ, Krogh PH Jr, Polizzi G, et al.. Osseointegrated implants for single tooth replacement: A 1-year report from a multicenter prospective study. Int J Oral Maxillofac Implants 1991;6:29-36.

2. Theoharidou A, Petridis HP, Tzannas K, Garefis P. Abutment screw loosening in single-implant restorations: a systematic review. Int J Oral Maxillofac Implants 2008;23:681-690.

3. Martin WC, Woody RD, Miller BH, Miller AW. Implant abutment screw rotations and preloads for four different screw materials and surfaces. J Prosthet Dent 2001;86:24-32.

4. Binon PP. Implants and components: entering the new millennium. Int J Oral Maxillofac Implants 2000;15:76-94.

5. Weng D, Nagata MJ, Bell M, Bosco AF, de Melo LG, Ritcher EJ. Influence of microgap location and configuration on the periimplant bone morphology in submerged implants. An experimental study in dogs. Clin Oral Implants Res 2008;19:1141-1147.

6. Canullo L, Quaranta A, Teles RP. The microbiota associated with implants restored with platform switching: a preliminary report. J Periodontol 2010;81:403-411.

7. Canullo $L$, lannello $G$, Gotz $W$. The influence of individual bone patterns on peri-implant bone loss: Preliminary report from a 3-year randomized clinical and histologic trial in patients treated with implants restored with matching-diameter abutments or the platform switching concept. Int J Oral Maxillofac Implants 2011;26:618-630.

8. Lazzara RJ, Porter SS. Platform switching: a new concept in implant dentistry for controlling postrestorative crestal bone levels. Int J Periodont Rest Dent 2006;26:9-17.
9. Maeda Y, Miura J, Taki I, Sogo M. Biomechanical analysis on platform switching: is there any biomechanical rationale? Clin Oral Implants Res 2007;18:581-584.

10. Cimen $\mathrm{H}$, Yengin E. Analyzing the effects of the platform-switching procedure on stresses in the bone and implant-abutment complex by 3-dimensional fem analysis. J Oral Implantol 2012;38:21-26.

11. Hsu ML, Chen FC, Kao HC, Cheng CK. Influence of off-axis loading of an anterior maxillary implant: A 3-D finite element analysis. Int J Oral Maxillofac Implants 2007;22:301-309.

12. Tabata LF, Assunção WG, Barão VAR, de Sousa EA, Gomes EA, Delben JA. Implant platform switching: biomechanical approach using twodimensional finite element analysis. J Craniofac Surg 2010;21:182-187.

13. Alvarez-Arenal A, Segura-Mori L, Gonzalez-Gonzalez I, Gago A. Stress distribution in the abutment and retention screw of a single implant supporting a prosthesis with platform switching. Int J Oral Maxillofac Implants 2013;28:112-121.

14. Yao KT, Kao HC, Cheng CK, Fang HW, Yip SW, Hsu ML. The effect of clockwise and counterclockwise twisting moments on abutment screw loosening. Clin Oral Implants Res 2012;23:1181-1186.

15. Dixon DL, Breeding LC, Sadler JP, McKay ML. Comparison of screw loosening, rotation, and deflection among three implant designs. J Prosthet Dent 1995;74:270-278.

16. Khraisat $A$, Hashimoto $A$, Nomura $S$, Miyakawa 0 . Effect of lateral cyclic loading on abutment screw loosening of an external hexagon implant system. J Prosthet Dent 2004;91:326-334.

17. Pellizzer $E_{\text {, Verri }}$, Falcón-Antenucci RM, Júnior JF, de Carvalho $P S$, de Moraes SL, et al.. Stress analysis in platform switching implants. A three-dimensional finite element study. J Oral Implantol 2012;38:587594.

18. Cibirka RM, Nelson SK, Lang BR, Rueggeberg FA. Examination of the implant-abutment interface after fatigue testing. J Prosthet Dent 2001;85:268-275.

19. Ekfeldt A, Eriksson A, Johansson LA. Stability of three screw joints in patients with implant-supported fixed prostheses in edentulous jaws: a 1-year follow-up study. Int J Prosthodont 2004;17:177-180.

20. Hecker DM, Eckert SE. Cyclic loading of implant-supported prostheses: changes in component fit over time. J Prosthet Dent 2003;89:346-351.

21. Jorge JRP, Barão VAR, Delben JA, Assunção WG. The role of implant/ abutment system on torque maintenance of retention screws and vertical misfit of implant-supported crowns before and after mechanical cycling. Int J Oral Maxillofac Implants 2013;28:415-422.

Received October 24, 2014 Accepted March 9, 2015 